University for Business and Technology in Kosovo

UBT Knowledge Center

UBT International Conference

2015 UBT International Conference

Nov 7th, 9:00 AM - 5:00 PM

\title{
Analysis of hotels - Case study Kosovo
}

\author{
Mimoza Sylejmani \\ University for Business and Technology, mimoza.sylejmani@ubt-uni.net \\ Lulzim Beqiri \\ University for Business and Technology, Ibeqiri@ubt-uni.net \\ Rineta Jashari \\ University for Business and Technology, rineta.jashari@ubt-uni.net
}

Follow this and additional works at: https://knowledgecenter.ubt-uni.net/conference

Part of the Architecture Commons

\section{Recommended Citation \\ Sylejmani, Mimoza; Beqiri, Lulzim; and Jashari, Rineta, "Analysis of hotels - Case study Kosovo" (2015). UBT International Conference. 58. \\ https://knowledgecenter.ubt-uni.net/conference/2015/all-events/58}

This Event is brought to you for free and open access by the Publication and Journals at UBT Knowledge Center. It has been accepted for inclusion in UBT International Conference by an authorized administrator of UBT Knowledge Center. For more information, please contact knowledge.center@ubt-uni.net. 


\title{
Analysis of hotels - Case study Kosovo
}

\author{
Mimoza Sylejmani ${ }^{1}$, Lulzim Beqiri ${ }^{1}$, Rineta Jashari ${ }^{1}$ \\ 1, UBT - Higher Education Institution; Prishtine, Republic of Kosovo \\ \{lbeqiri1, mimoza.sylejmani1, rineta.jashari1\}@ubt-uni.net
}

\begin{abstract}
The research deals with the analy sis of the Hotels, where as a case study is taken Kosovo. Focus study were the cities with the greatest number of people, namely those which are visited more by tourists. The research is based on analy tical method, which helps in the final results. Analyzed in terms of functional objects, architectural, access to the facility, their capacity and conditions that they offer guests. The classification of buildings is done in two groups;

a) Those built before 1999 and

b) Those built after 1999 .

Analy sis show that cases of hotels built before 1999, which once met all the requirements in terms of functional, architectural and urban planning, today some of them lack any of the basic elements, characteristic of a hotel.

Furthermore, from analysis few hotels built after 1999, meet the functional elements in terms of interior space, but on the other hand they lack in urban and architectural aspects.
\end{abstract}

Keywords: Location, architecture, supply, capacity, function.

\section{Introduction}

During the design of hotel buildings every time there has existed the effort that they have to be positioned in the city center, where circulation of citizens is more pronounced. As a result of overcrowding in the city of Pristina, the possibility of building such an object was minimized.

Adaptation of buildings of different characters in hotel facilities became part of our reality, giving a new breath to this type of residential facilities, without contained in itself the elegance and comfort, these elements characteristic of an object of this kind.

The need to build something beautiful which in itself will contain the necessary elements for a stay cozy, encouraged the investor for the construction of these facilities on the outskirts of our city. This allowing in this way the parking lot sufficient for clients, as opposed in the cases mentioned above, but concurrently removing this ty pe of facilities from the city center. Hotel facilities built before 1999, during the periodic renovations they lost the key appearance in the interior as well as exterior, these changes in some cases positive, while in some cases have lost the values of the object. The aim of the research has been to identify shortcomings under these facilities. 


\section{The methodology}

Methods which are used are:

1. The comparative method and

2. Analy tical method

These methods have helped in achieving the final results during this research.

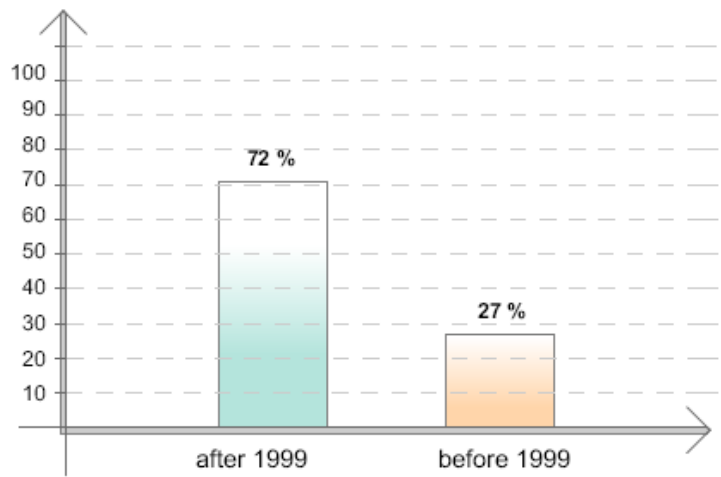

Figure 1. Analy sis of hotels build before and after war 1999.

(Source; Author's figure in October 2015)

In the diagram is shown number of hotels analyzed before and after the war in percentage.

The largest number of hotels are built in cities and on the highway roads, while a smaller number were constructed in mountainous parts of the country as Hotel Sharri, Magra Austria etc.

\subsection{The comparative method}

During the research there were analy zed there considerable number of hotel facilities built in Kosovo. Amongst them we have presented two examples of these objects built before and after 1999. The facilities were compared in architectonic terms, whereas the key point of the research were: the access in object, the dimension of sleep units and analy sis of constructive spaces.

- Hotel Dukagjini was built in 1956 in the city of Peja. The building is located $300 \mathrm{~m}$ away from the bus station and $70 \mathrm{~km}$ away from Pristina Airport. It is one of characteristic hotels built in our country, situated along the White River, just few steps away from the business area, theater, bars and other buildings of cultural heritage. The building is made from circumstantial materials such as stone and wood, offering thus a warmth to guests, but during occasionally renovations, among these materials are introduced other materials such as: plastic, aluminum and glass, by losing the authenticity of the concerned object.

- Golden Hotel, was built in 2013 in Pristina. The hotel is located about 20 minutes from the city center. It has $\mathrm{G}+2$ story height, and ample space for parking.

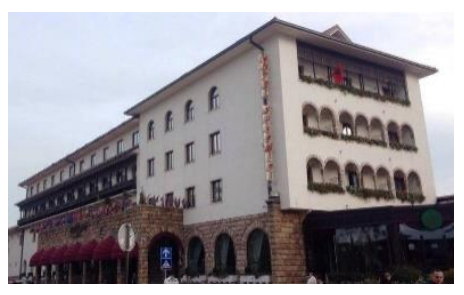

Figure 2. Hotel Dukagjini - Peja (Source; Author's photography in October 2015)

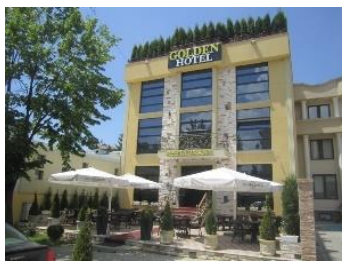

Figure 6. Hotel Golden - Pristina (Source; Author's photography in in May 2015) 


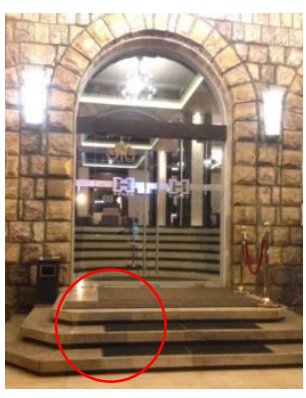

Figure 3. Main entrance in Hotel Dukagiini (Source; Author's photography in

October 2015)

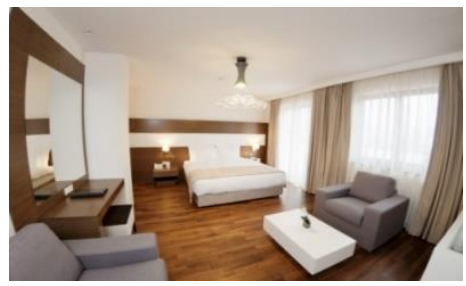

Figura4.Interior of the room Hotel Golde

(Source; Author's photography in October 2015)

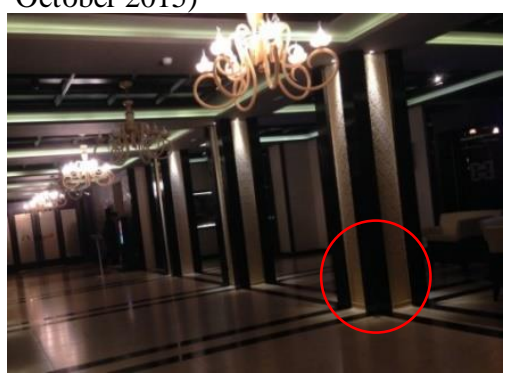

Figure 5. Interior hall-Hotel Dukagjini (Source; Author's photography in October 2015)

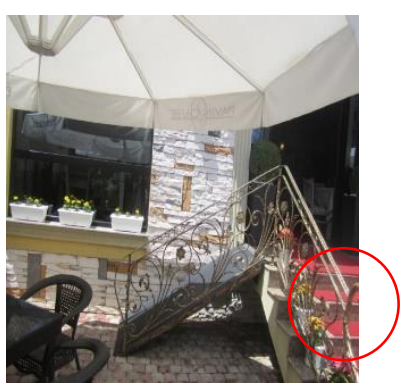

Figure 7. Vertical communication (Source; Author's photography in May 2015)

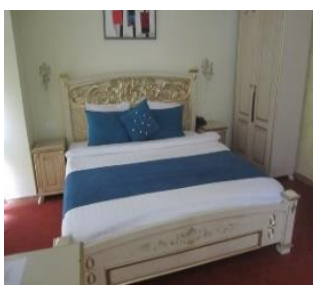

Figure8. Interior of the room Hotel Dukagjini

(Source; Author's photography in May 2015)

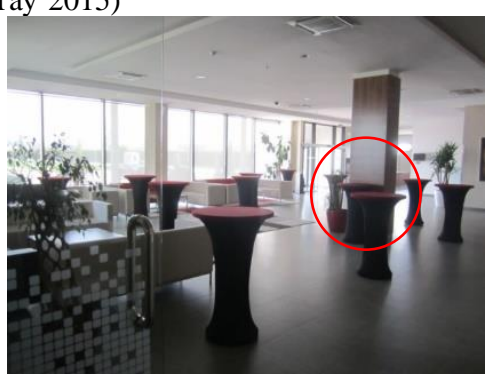

Figure 9.Interior hall -Hotel Golden (Source; Author's photography in May 2015)

Today the development of the technology offers great opportunities in both constructive and aesthetic aspect. Further, today the use of different systems constructive enables large static spaces, therefore the elimination of the pillars in the necessary spaces in functional terms which appear as obstacles can be achieved more easily, which this technology is not noticed that it is applied in new hotelier buildings. 


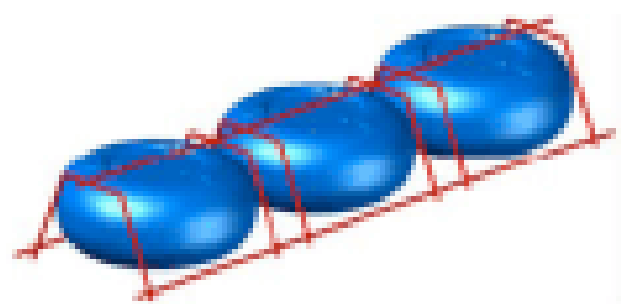

Figure 10. Slim -Line-Cobiax

(Source; Cobiax Engineering Manual 2010)

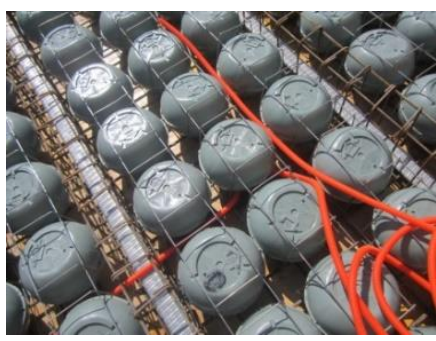

Figure 11. The relieved slab Source; Author's photography in March 2012)

\subsection{The analytical method}

Over the time, many of the hotels have changed their structure, by downgrading the values that they had before. This degradation in most cases comes at the time of their renovation by private investors, as a result of using inadequate materials and improper combinations.

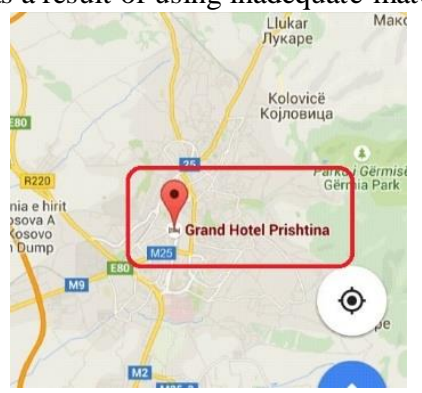

Figure 12. Location of Grand Hotel (Source; Google Map 2015)

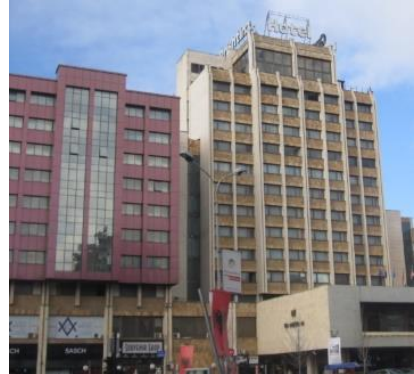

Figure 13. Grand Hotel (Source; Author's photography in November 2015)

Grand Hotel which is located in the center of the city of Pristina during external renovation changed its appearance, causing reactions and dissatisfaction on the part of citizens. Therefore, today one part of the hotel with the rest of it do not correspond with each other. In this case the investor worked zealous in the so-called "ugliness of our center", is one of our citizens' comments.

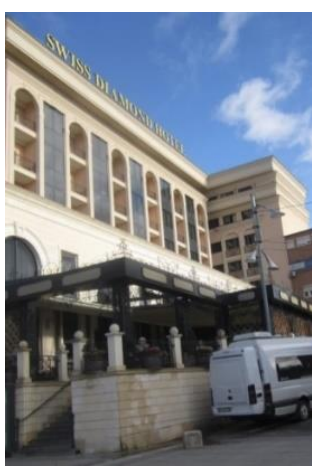

Figure 14. Swiss Diamond Hotel (Source; Author's photography in October 2015)

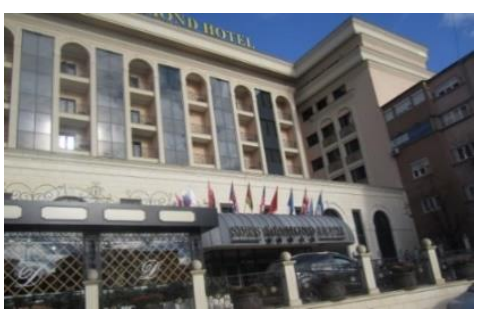

Figure 15. Main entrance in Swiss hotel (Source; Author's photography in October 2015) 
During the time, some of the hotels have lost any of the advantages that had once, as a result of changes that time has brought. Aforetime, the access to the hotel today so-called Swiss Diamond Hotel could be realized by two parallel streets, offering a high comfort of access to the building. Meanwhile, today as a result of changes in urbanistic aspect, one of the streets has become Main Square, by imposing access to the hotel only by his rear.

\section{Conclusion}

The aim of this paper was to identify difference in accommodation-living space and comfort of hotel spaces dedicated to visitor and we are confident to present through this paper findings in this relation. Based on the analysis done and data integration to this research, we came to the conclusion that residential hotel facilities built before 1999 offers higher commodity and conditions for guests compared with those built after 1999 in functional terms, while in the aesthetic aspect were competing. Those findings we do based on survey and analy ses completed for this research and as well compare to the standards related to interior living space of standard hotels. Today, the development of technology offer great op portunities in both the constructive and aesthetic asp ect, however, we noticed that these advantages are not exploited in the cases mentioned above. There are some indicators that leads us to the conclusion that some of the hotels were adapted, as their initial function was dedicated for another function. Furthermore having in consideration post conflict period, missing of development planes and professional building companies indirectly influenced the comfort of hotel spaces. The post conflict time reflected on hotels ownership, as before conflict hotels were socially owned that went through privatization process and therefore private owner, through refurbishment process affected a lot hotels values in interior and exterior. On the whole, such buildings in case of privatization were reconstructed, but during this process became inadequate combinations of materials were done causing the degradation of their values. The analy ses clearly identified that before and after 1999 in a very few cases was treated access of visitors with special needs. Approach to hotels for visitors with special needs, their vertical and horizontal communication can be clearly seen as nontreated or in minor level treated before and after 1999. Main elements are ramps for people with special needs and elevators with inadequate dimensions, but in some cases even don't exist, which can make it difficult or without enabling them access in hotels. Through this paper as well was identified size reduction at bedrooms unit that indirectly increased number of visitors (business aim approach) but reduced common places as communication, restaurants, and hotel lobby etc. therefore in most of the cases those were minimized. Above mentioned factor, scanning of current situation and comparing to space demand at the hotels, expressed though commodity, and confronting the space reduction, followed with construction elements and materials used unprofessionally, it is necessary to have a professional approach to this problem by try ing to set up local standards, based on international standards, and implement local regulation and law related to hotel design. Creating or adhering one technical regulations, without which the designers and investors will not be allowed to construct such characteristic buildings, would help improving the situation in which construction of hotels and hotel spaces is today.

\section{References}

1. New Hotels - Alejandro Bahamon

2. Design Hotels - Architectural Design

4. Engineering Manual Issue 2010, Cobiax Technologies, www.cobiax.com

5. https://www.google.com/maps/@42.6602342,21.1599785,18.25z (fig.12) 01.11.2015

5. New Hotel: Architecture and Design (15 Jun 2001) - by David Collins

6. 101 Hotel-Lobbies, Bars \& Restaurants (7 December 2013) by Corinna Kretschmar Joehnk and

Peter Joehnk

7. Hotel Architecture (Aug 2011) by Orange Yan

8. Hotel Design, Planning, and Development (Second Edition) (by Richard H. Penner, Lawrence

Adams and Stephani K A Robson

9. Detail in Contemporary Hotel Design (10 September 2013) by Drew Plunkett and Olga Reid 